\title{
Steroidal Aromatase Inhibitor
}

National Cancer Institute

\section{Source}

National Cancer Institute. Steroidal Aromatase Inhibitor. NCI Thesaurus. Code C2017.

An aromatase inhibitor with a steroidal structure. Steroidal aromatase inhibitors work by forming a permanent bond with the enzyme. 